\title{
Indigenus Inclusive Education Concept Based on Ki Hadjar Dewantara Values and Dysontogenesis Vygotsky Theory
}

\author{
Asri Wijiastuti $^{1 *}$, Siti Masitoh ${ }^{1}$, Ima Kurrotun Aini ${ }^{1}$, Febrita Ardianingsih $^{1}$ \\ ${ }^{1}$ Universitas Negeri Surabaya, Indonesia \\ *Corresponding author.Email: asriwijiastuti@unesa.ac.id
}

\begin{abstract}
The conceptualization of inclusive education more practical level than its basic concept. The purpose of this study is to dissect and trace Ki Hadjar Dewantara's values and Vygotsky's dysontogenesis theory in the implementation of inclusive education. The research design used was ethnographic qualitative research. This ethnographic research used data collection methods: (1) Study of Vygotsky's theory documents, (2) Focus group discussion, (3) Questionnaire to teachers, and policy makers. The results of the analysis of the position of Vygotsky's theory in the implementation of inclusive education in the concept of the dysontogenesis are focused on how children construct knowledge according to their culture and ways. The dysontogenesis concept which focuses on positive differentiation emerged around 1993 which in Indonesia itself had been developed by Ki Hadjar Dewantara in 1913-1919 the emphasis was on teaching according to the nature of the child. Ki Hadjar's philosophy is heavily influenced by Maria Montessori's thoughts which emphasize the value of children's independent activities and the importance of children's growth as individuals. In 1952 he created a "system of learning" approach. The system that supports the child's natural nature in order to develop inner and outer life according to his own nature. Knowledge and intelligence are only tools, the fruit is the maturity of the soul that can realize life and livelihood in an orderly, holy, and useful for others. The concepts of dysontogenesis and nature of the child are in harmony in looking at the cognitive and children's efforts in obtaining the concept of knowledge.
\end{abstract}

Keywords: Inclusive education, indigenous, dysontogenesis, child nature

\section{INTRODUCTION}

Indonesia has implemented inculsive education for more than three decades but the teacher's perceptions and attitudes have not met expectations. According to the results of research on the PKLK found a number of 5,717 teachers have a constructive attitude towards theeducation inclusive implementation which should have a deep understanding.

De Boer, Pijl, \& Minnaert (2010) states that positive teacher attitudes and expectations are important for successful inclusion. Teachers who have a positive attitude towards inclusion tend to be better equipped to adjust their approaches to be able to answer the different learning needs of students Subban \& Sharma, 2006). Karsidi (2015) in his scientific speech stated that inclusive education is still understood by the community as merely providing a place and space for children with special needs in regular schools because it meets the demands of the world. This understanding must be straightened out that inclusive education should be understood as an education system that is oriented towards expanding access, improving quality, and relevance of education in a broad sense.

Look at the Minister of Education's speech at the commemoration of National Teacher's Day which states "You know that every child has different needs but uniformity has outperformed diversity". The statement requires that children in inclusive education mean schools must accommodate all children regardless of physical, intellectual, social-emotional, linguistic or other conditions. This must include children with disabilities and gifted children, street children and working children, children from rural areas, or who are mobile, children from ethnic minorities, linguistics or culture and children from disadvantaged or marginalized areas or groups (Salamanca, 1994). Another opinion states that inclusive education is the placement of children with mild, moderate and severe disabilities in full class (Staub and Peck, 1995). These two opinions actually give us an understanding that inclusive education is an effort to provide opportunities for all (reguler children and children with special needs) in obtaining education. With the diverse types of children 
with special needs, it means that there will also be a diverse composition of students in the inclusive class. Referring to another sentence in the Minister of Education's speech is "I will not make empty promises to you". Change is difficult and full of inconvenience. One thing is for sure I will fight for the independence of learning Indonesia ". The statement is very closely related to the concept of inclusive education which prioritizes the freedom and freedom of the soul of children in learning in accordance with nature. The concept which is based and related on $\mathrm{Ki}$ Hadjar Dewantara's thought and dysontogenesis theory is to the existence of children with special needs in regular classes in the effort to implement inclusive education in Indonesia. There are not many analytic studies or research findings that question the Grand Theory which underlies inclusive education. This question is very intriguing to be followed up through research. Greenspan (1998) revealed that to enable children to learn to interact, it is very important to blend children with special needs with other children who are not problematic. Another theory states that once a child with special needs should study together with normal children, in order to be able to interact socially (Vygotsky, 2007).

These two opinions seem to have almost the same meaning, but actually there are differences in meaning. Related to the concept of implementing inclusive education, it is suspected that Vygotsky's theory which is the foundation of philosophy and science as well as local wisdom as initiated by Ki Hadjar Dewantara has not been studied in depth in the research corridor.

The response of 55 teachers in Pidie Jaya from 20 inclusive schools and 1 special school from Fajrillah's research (2018) perceived that inclusive education was implemented by separating children with special needs and regular children. The perception that is still not in accordance with the nature of the implementation of inclusive education is due to the lack of provisioning and training of special assistant teachers. Whereas the results of the Oktadra analysis (2016) state that school principals' perceptions related to inclusive education are the concept of presenting education as a whole relating to openness in accepting children with special needs to obtain their basic rights as citizens.

Some studies describe teachers as positive, negative, and neutral. Subban \& Sharma (2006) in Australia, Idol (2006) in the United States, Gal, Schreur, \& EngelYeger (2010) in Israel, Kochen \& Radford (2011) in Lebanon, and Todorovic, Stojiljkovic, Ristanic, Ristanic, and Djigic (2011) in Serbia, Kurniawati et al (2012) in Indonesia, and Qi, Wang \& Ha (2016) in Hong Kong. Chiner and Cardona (2012) also report positive teacher attitudes even though teacher skills, time, material resources and personal support for inclusion are insufficient.
Rakap and Kaczmarek (2010) in Turkey, Hwang and Evans (2011) in Korea, and Hofman and Kilimo (2014) in Tanzania. Gaad and Khan (2007) point out the lack of teacher skills and teachers feel a heavy burden in meeting the needs of students with special needs who describe negative attitudes. While the neutral attitude of the teacher is illustrated from the results of research by Hsieh and Hsieh (2011), Savolainen, Engelbrecht, Nel, and Malinen (2011), Helldin et al (2011) revealed that teachers in Sweden. In essence, humans as creatures that can be educated (animal educable) and must be educated (animal educandum). For this reason, a school education institution is needed as a vehicle for the ongoing education process, in this case educated (which must be educated) consists of regular children and children with special needs with various types of disorders. They have the same rights in obtaining education by respecting the strengths and weaknesses of each.

\section{METHOD}

Research on the concept of inclusive education is based on critical analysis of Ki Hadjar Dewantara's teaching values and Vygotsky's theory, using a qualitative research approach of ethnographic design. This ethnographic research used data collection methods (1) Study documents of Ki Hadjar Dewantara's values and Vygotsky's theory written by Vygotsky and his adherents related to the concept of implementing inclusive education, (2) focus group discussions (FGD) to analyze between theory and implementation inclusive education in accordance with the values taught and written by Ki Hadjar Dewantara and Vygotsky's Theory, (3) Questionnaire to teachers, and policy makers related to understanding Ki Hadjar Dewantara's paradigm and Vygotsky's theory in the implementation of inclusive education. The research subjects consisted of (1) teachers, (2) inclusive school principals and (3) policy makers related to the implementation of inclusive education. The data analysis technique uses the analysis technique of Miles and Hubermen (2012). Valid and credible data checking, in this study using data validity techniques by conducting: (1) Triangulation of methods, namely checking the degree of trust in research findings from data collection techniques through document, FGD and questionnaire methods, (2) Triangulation of sources, in this case field findings, checking the correctness of the data by comparing information, the researcher controlled again by checking the truth of the research findings to several respondents. Data confirmation can be made to teachers, principals or policy makers as providers of inclusive education, (3) Triangulation of theory is used in connection with research findings with the withdrawal of premises based on relevant theories. In this study referring to the proof of the problem formulation with the research findings. 


\section{FINDING AND DISCUSSION}

\section{Finding(s)}

The results of an analytical study of the position of Vygotsky's Theory in the implementation of inclusive education. Departing from socio-cultural thinking and local wisdom related to the meaning of the concept and implementation of inclusive education in Indonesia, the team agreed to explore interview and written information on the legacy of Ki Hadjar Dewantara's educational philosophy. Ki Hadjar's philosophy, which is implemented in the world of teaching contained in the "Teachings of Student Affairs" is still preserved and becomes a main thing that must be mastered by lecturers, students and teachers who are in the student park education environment. In the presentation which will be elaborated from the results of observations and interviews related to the position of Vygotsky's theory in the implementation of inclusive education as follows.

Pandangan Ki Hadjar Dewantara's view of disability in the context of inclusive education

Paradigm which strongly supports the inclusive education implementation is a document written "Children live and grow according to their own nature, education can only nurture and guide the growth of that nature. This is consistent with Ki Hadjar's statement when receiving an Honoris Causa (HC) Doctorate Degree from UGM in 1956 in 60 years Taman Siswa described the analogous relationship between teacherstudent and farmers and their crops. Teachers as educators of students must think, feel, and behave as Farmers for their plants. People who grow crops must submit to the nature of the plant, let the plants not be conquered by the will of the farmer. The farmer must surrender himself, that is, eliminate his own wrath, with sincerity and pleasure in the interests of his crops and pursue purely plant fertility. The fertility of these plants is in the interests of the farmer. He must know the difference between rice, corn and other plants in their respective needs to be able to grow well and be successful.

Therefore, it is necessary for the farmer to know, be aware and do all agricultural knowledge, which is true and good. In the meantime, do not discriminate between where fertilizer comes from, tools, or agricultural science came from, and so on; everything that can fertilize plants according to their nature and irodate must be used by them (farmers). The context and statement of this analogy are very relevant to the meaning of inclusive education which must prioritize the nature and irodat of children not as coercion in obtaining a concept of knowledge.

Vygotsky view of disability in the context of inclusive education

Critical analysis studies are focused on the fundamental concepts of Vygotsky's theory in terms of dysontogenesis, which is presented as a view of social construction on disability, a psychological cultural history that underlies the "Russian model" of inclusive education in today's preschool. Vygotsky's views regarding inclusive education depart from Vygotsky's theory "The Fundamentals of Defectology" which was first published in the UK in 1993, related to the framework of special education and psychological methodologies relevant to the implementation of inclusive education today. Vygotsky in Russia worked in the fields of special education and psychology which were important in developing the methodology of special education practices.

Vygotsky's views related to disability, theoretical concepts and methodologies concerning special education in the research studies conducted largely escaped the attention of even many who were ignored. Vygotsky formulated the paradigm of educational practice for Children with Special Needs. This theory asserts that individual cognitive acquisition occurs first through intrapersonal interpersonal (interaction with the social environment) (internalization that occurs within oneself). Vygotsky's social construction theory in epistemology is the basis for the development of special education in the future, namely inclusion based on positive differentiation (Gindis, 2003). According to Vygotsky's dysontogenesis theory, the positive source orientation approach has implications for the diverse views of society related to children with special needs, giving preference to strengthening and empowering individual skills compared to traditional stress on weaknesses or deviations. Critical analysis studies mainly focus on the view of social construction on disability, Vygotsky's theory related to dysontogenesis (dys-anomaly, ontos-being, genesis-development, deviant growth and development compared to growth and development of regular individuals), and implementation of inclusive education practices.

\section{$\operatorname{Discussion}(\mathbf{s})$}

The results of interviews with Ki Priyoko, the heir and successor to the teachings of Ki Hadjar, stated that Ki Hadjar never distinguished anyone. Fatwa stating "educate children according to their nature". Ki Hadjar gives democratic freedom, everyone has the right to freedom in any matter until it produces the song "......", which he then silently discontinued, and he stated with the limits do not interfere with others. This context shows the meaning of inclusive education in the implementation of Pawiyatan that organizes inclusive schools, while in Higher Education, although it is not labeled as inclusive, in principle it does not reject the existence of students with disabilities. One of the graduate students with disabilities Pak $\mathrm{S}$ who is a member of the Solider community. In fact, according to Ki Priyoko, a lecturer who teaches at UST is also a person with a disability. In principle, together in 
teaching and building the tenacity of Tamansiswa teachings inherited by Ki Hadjar.

Adequate resources include the provision of suitable accommodation, individual plans, and inclusive teaching methods (Khochen \& Radford, 2011). Adequate support includes sharing information and strategies with students with disabilities with other professionals such as special education teachers, teacher assistants (Sukbunpant et al., 2012) and school psychologists (Boyle, Topping, JindalSnape, \& Norwich, 2012). Teachers will provide positive perceptions related to inclusive education requiring adequate external support to be able to provide holistic and comprehensive services. The basic need is a correct understanding related to inclusive education. In accordance with Karsidi's scientific speech (2015) that has read the results of Joseph's survey report in 2015 in East Java and Central Java that found the level of community trust related to the implementation of inclusive education that is able to foster local strengths and potential, which in the end was able to encourage the growth of inclusive communities.

Vygotsky's theory focuses on the dynamic nature of disability is important in the special didactic aspects that take into account the constant changes in the structure and content of the disability development process that is influenced by education and remedial (Gindis, 2003: 204). Vygotsky regards disability as a "social deviation" (1993: 66), by not ignoring biological development. According to Vygotsky "social deviations" depart from changes in social relations, children's environment that causes social behavior disorders. The main focus of reason regarding disability exclusively implies the impression of disregarding the disability development process

\section{CONCLUSSION}

The foundation of the philosophy of the Soul of independence and the principle of appealing to $\mathrm{Ki}$ Hadjar Dewantara is the basis of the concept of inclusive education in Indonesia which is very closely related to the socio-cultural and scientific characteristics of the substance of Vygotsky's theory in the implementation of inclusive education that further elaborates diversity. The analysis related to the teacher's role in the implementation of inclusive education rests on $\mathrm{Ki}$ Hadjar's view between the farmer and his plant and Vygotsky's view related to dysontogenesis illustrates how important a teacher's understanding and positive attitude is towards the presence of children with special needs in the regular class.

Inclusive education in this case does not merely glue socio-cultural values in the nation amid cultural differences that will minimize all forms of discrimination, violence and injustice but can instill a way of life respecting, sincere, and tolerant of diversity in the midst of a plural society. Achievement of socio- cultural education can be optimally inseparable from the role and support of teachers, educational institutions, and educational policy makers in understanding the concept of inclusive education in applying the curriculum with a multicultural approach. The indigenus concepts of dysontogenesis and nature of the child are in harmony in looking at the cognitive and children's efforts in obtaining the concept of knowledge.

\section{REFERENCES}

De Boer, Pijl, \& Minnaert (2010). Regular primary schoolteachers' attitudes towards inclusive education: a review of the literature. International Journal of Inclusive Education, 15(3), 331-353. doi:10.1080/ 1360311090303 0089

Subban, P., \& Sharma, U. (2006). Primary school teachers' perceptions of inclusive education in Victoria, Australia. International Journal of Special Education, 21(1), 42-52.

Karsidi (2015). Rektor Universitas Sebelas Maret Surakarta yang dibacakan pada Dies Natalis ke 65 Fakultas Ilmu Pendidikan Universitas Negeri Yogyakarta tanggal 14 Agustus 2015

Salanmanca statement. (1994). On principles, policy and practice in special needs education.

Staub, D., Peck, C.I, (1995). What are the outcames for nondsability students?. Educational leadership Journal of the Department of Supervision and Curriculum Development, NEA. Retrieved from : https://www. net/publication/234608288

Dewantara. Ki Hadjar. (1977). Karya Ki Hadjar Dewantara bagian pertama: pendidikan. Yogyakarta: Majelis Luhur Persatuan Tamansiswa.

Vygotsky, L. S., 2007. Development of Children and the Process of Learning, Cambridge. MA: Harvard University Press, terj. Yogyakarata: Pustaka Pelajar.

Fajrillah, Mashadi, Zakiah, Nurjasmi, Miftahul Jannah (2018). Persepsi Guru Terhadap Pelaksanaan Pendidikan Inklusi di Pidie Jaya Jurnal Geuthèë: Penelitian Multidisiplin, Vol.01, No. 01

Oktradiksa, A. Analisis persepsi guru Madrasah tentang konsep sekolah inklusi di MI Muhammadiyah Jagalan Kabupaten Magelang.Retrieved February 15, 2020, from http://www.google.com/

Idol, L. (2006). Toward Inclusion of Special Education Students in General Education: A Program Evaluation of Eight Schools. Remedial and Special Education, 27(2), 77-94. doi: 10.1177/07419325060270020601

Gal, E., Schreur, N., \& Engel-Yeger, B. (2010) Inclusion of Children with Disabilities: Teachers Attitudes and Requirements for Environmental 
Accommodations. International Journal of Special Education, 25(2), 89-99.

Khochen, M., \& Radford, J. (2011). Attitudes of teachers and headteachers towards inclusion in Lebanon. International Journal of Inclusive Education, 16(2), 139-153. doi: $10.1080 / 13603111003671665$

Kurniawati, F., Minnaert, A., Mangunsong, F., \& Ahmed, W. (2012). Empirical Study on Primary School Teachers' Attitudes Towards Inclusive Education in Jakarta, Indonesia. Procedia - Social and Behavioral Sciences, 69(0), 1430-1436. doi: 10.1016/j.sbspro.2012.12.082

Hwang, Y.-S., \& Evans, D. (2011). Attitudes towards inclusion: gaps between belief and practice. International Journal of Special Education, 26(1), 136-146.

Chiner, E., \& Cardona, M. C. (2012). Inclusive education in Spain: how do skills, resources, and supports affect regular education teachers' perceptions of inclusion? International Journal of Inclusive Education, 17(5), 526-541. doi: 10.1080/13603116.2012.689864

Creswell, J. W. (2013). Qualitative Inquiry \& Research Design: Choosing Among Five Aproaches, Third Edition. London: Sage Publication.

Milles, M. B \& Huberman, A. M. (2012) Quality Data Analysis: A. Source Book of New Method. London: Sage Publication.

Direktorat PLB Ditjen Dikdasmen Depdiknas. (2003). Pedoman penyelenggaraan pendidikan terpadu/inklusi: Buku 1 Mengenal pendidikan terpadu/inklusi. Jakarta: Depdiknas.

Gindis.B. (1999). Vygotsky's Vision: Reshaping the practice of Spcecial education for the $21 \mathrm{st}$ Century. Remedial and Special Education Journal. Vol.20. No.6.pp.32-64

Gindis, B. (1994). Vygotsky's Defectology (book review on: "The Fundamentals of Defectology: Abnormal Psychology and Learning Disability"). American Journal on Mental Retardation, Vol. 100, \#2, pp. 214-216

Katarina A. Rodina. (2005). Vygotsky`s Social Constructionist View on Disability: A Methodology for Inclusive Education, Desertasi. Department of Special Needs education, University of Oslo, Norway.

Rakap, S., \& Kaczmarek, L. (2010). Teachers' attitudes towards inclusion in Turkey. European Journal of Special Needs Education, 25(1), 59-75. doi: 10.1080/08856250903450848 